
\title{
28 Research Suare \\ Effect of low-intensity ultrasound on the colonization of spermatogonial stem cells
}

\section{Zeinab Hormozi Moghaddam}

Tarbiat Modares University Faculty of Medical Sciences

Manijhe Mokhtari-Dizaji ( $\nabla$ mokhtarm@modares.ac.ir)

Tarbiat Modares University Faculty of Medical Sciences

Mansoureh Movahedin

Tarbiat Modares University Faculty of Medical Sciences

Research article

Keywords: Low-level-intensity ultrasound, Mechanical index, Spermatogonial stem cells, Colonization, Viability

Posted Date: December 17th, 2019

DOI: https://doi.org/10.21203/rs.2.19073/v1

License: (c) (1) This work is licensed under a Creative Commons Attribution 4.0 International License. Read Full License 


\section{Abstract}

Background: Low-level-intensity ultrasound waves contribute to the proliferation, differentiation, and increasing the number of cells in vitro. However, the interaction of ultrasonic waves involving thermal effects, mechanical vibration, or cavitation as a cell proliferation factor has not been determined. Therefore, the aim of this study was to investigate the effect of cavitation (mechanical index) on spermatogonial stem cell proliferation and colonization by removing heat effects caused by ultrasound radiation. Isolated spermatogonial stem cells from neonatal mice were cultured in a DMEM culture medium with $10 \%$ FBS. Spermatogonial stem cells were stimulated by low-level ultrasound for five days and colonization and viability were evaluated on the $7^{\text {th }}$ day.

Results: Regarding the low intensity of ultrasound, the Rayleigh integral model was used for acoustic pressure computation. According to the results of modeling, the intensities of $0.28,0.45,0.96$, and 1.34 $\mathrm{W} / \mathrm{cm}^{2}$ were selected at $0.5 \mathrm{~cm}$ of distance with the mechanical indices of $0.40,0.51,0.75$, and 0.89 . The mechanical indices of 0.40 and 0.89 resulted in $93 \pm 4$ and $32 \pm 4$ colonies, respectively. An increase in colony diameter was observed for the mechanical index of 0.40 during all days of the culture. In the culture on the $7^{\text {th }}$ day, it had the largest average colony diameter of $134.05 \pm 1.22 \mu \mathrm{m}$ in comparison with other groups $(p<0.05)$. Cell viability did not significantly differ across groups $(p=0.08)$.

Conclusion: The results suggest that a low-intensity ultrasound of $40 \mathrm{kHz}$ with a 0.40 mechanical index can be effective in increasing the proliferation and colonization of spermatogonial stem cells during culture. In other words, a mechanical index within the threshold of cavitation increases the proliferation and colonization of spermatogonial stem cells.

\section{Background}

Recently, biostimulation with low-intensity ultrasound (LIUS) has been studied in the proliferation and differentiation of stem cells in vitro [1]. Low-frequency ultrasound (LF) has a wide range of therapeutic and industrial applications, and novel emerging usages are being introduced in this range [2].

Researchers believe that biochemical and mechanical stimulation conditions are necessary for the proliferation and differentiation of stem cells $[3,4]$, and lack of elasticity and mechanical stress reduce the stem cell differentiation $[5,6]$. Moreover, several studies on stem cells such as dental, blood, and spermatogonial stem cells (SSCs) have been conducted by low-intensity ultrasound waves [7]. SSCs are valuable stem cells in treatment and research [8]. Understanding the process of spermatogenesis is essential, and it can be a great help in treating infertile men [9]. Colonization of spermatogonial cells is an important part of the treatment of infertility, germ cell gene change, cell transfection, and differentiation of SSCs in vitro [10]. Cellular responses to low-intensity ultrasound are parameter-dependent [11]. In general, ultrasound biological effects consist of thermal and non-thermal (acoustic cavitation) effects [12]. To increase the effect of ultrasound waves in molecular and cellular dimensions, a process is 
required for transmitting ultrasonic wave energy to these small dimensions. The phenomenon of acoustic cavitation can induce this effect $[13,14]$.

Acoustic cavitation is classified into stable and inertial cavitation. Stable cavitation is the continuous oscillation of acoustic cavitation over a large number of cycles driven by the pressure fluctuations of the applied acoustic field. This type of cavitation typically produces highly localized acoustic streaming which may cause shear stresses on a nearby cell. Inertial cavitation is a transient type of cavitation where the acoustic cavitation oscillates heavily over a single or multiple cycles, eventually leading to a violent collapse/implosion. The collapse is associated with localized high pressures and temperatures and highvelocity liquid jets [15]. Mechanical index (MI) was introduced by Apfel and Holland (1991) as a quantity expressing the biological effects of cavitation $[14,16]$.

There is growing evidence that integrins are promising candidates for sensing extracellular matrix-derived mechanical stimuli and converting them into biochemical signals. Mechanical stimuli can affect both the actin cytoskeleton and cell cycle progression. Direct mechanical stimulation such as the stretching of cells can activate the extracellular-signal-regulated kinase (ERK) pathway in different cell systems, leading to cell proliferation. Acoustic cavitation interaction of low-intensity ultrasound can be regarded as a form of nonphysiological mechanical energy indirectly applying mechanical stress to the cultured cells [17]. Nevertheless, in all studies, specific sonication conditions are determined by considering the availability of the radiation frequency without physical or mechanical reasons or the explanation of the mechanism type [18], and the interaction of low-intensity (low-frequency) ultrasound has not been studied. In our previous study [19], we calculated the acoustic pressure in the medium by ultrasonic propagation based on a tissue-inducing Rayleigh integral model in which wave equations were linearly calculated in a homogeneous environment. Then, it was used to extract the physical parameters of acoustic pressure and mechanical index. In the present study, the effect of these parameters on SSC viability and colonization was evaluated using a quantitative approach to investigate the effect of the MI of LF and LIUS on spermatogonial stem cell colonization by removing heat effects caused by ultrasound radiation.

\section{Methods}

The pressure equation was solved at any point in cylindrical coordinates and extracted minimum acoustic pressure $\left(\mathrm{P}_{\mathrm{min}}\right)$. To extract the MI plan, acoustic variables included the frequency of $40 \mathrm{kHz}$ (Ultrasound Laboratory, Medical Physics Department, Tarbiat Modares University, Iran), acoustic intensity of 0 to $1.34 \mathrm{~W} / \mathrm{cm}^{2}$, and the continuous exposure mode. Modeling was performed in $32^{\circ} \mathrm{C}$ water (in vitro) with the density of $1000 \mathrm{~kg} / \mathrm{m}^{3}$, acoustic propagation speed of $1519 \mathrm{~m} / \mathrm{s}$, and attenuation coefficient of $0.002 \mathrm{~N} / \mathrm{MHz}$ [20]. For validation, acoustic pressure was calculated at different distances and compared with the experimental results [19]. Based on the experimental study, the target radius was equal to the hydrophone piston radius (PA124, Precision Acoustics Ltd., Dorchester, UK, $1.3 \mathrm{~cm}$ sensor radius). The MI according to the intended frequency $(f)$ and the minimum acoustic pressure $P_{\min }$ was defined as: 
This was applied within the frequency range of $0.5-15 \mathrm{MHz}$, but Ahmadi [21] showed that it is an appropriate index for frequencies below about $500 \mathrm{kHz}$.

The present study was conducted under the protocol approved by the Animal Experimental Committee of the Medical Sciences Faculty of Tarbiat Modares University.

Isolation and culture of SSCs from neonatal mice (NMRI, National Medical Research Institute) was performed according to the specified protocol [19]. The animals were euthanized quickly and humanely to avoid any pain by overdose of chemical anesthetics (2-3 times the anesthetic dose) and confirmed by heart tissue harvest [22]. The testicles were extracted for $10 \mathrm{~min}$ and collected after washing in Dulbecco's Minimum Essential Medium (DMEM), placed in a new medium. After the removal of the capsule, the testicles were cut into smaller pieces and placed in a culture medium containing $0.5 \mathrm{mg} / \mathrm{ml}$ of collagenase IV (Sigma) and incubated at $37^{\circ} \mathrm{C}$ for $20 \mathrm{~min}$, then centrifuged for 5 min with $1500 \mathrm{rpm}$. Afterwards, the medium was plaque exchanged with PBS and centrifuged twice for $3 \mathrm{~min}$ at $1000 \mathrm{rpm}$. Next, $0.5 \mathrm{mg} / \mathrm{ml}$ of trypsin (Sigma) was added to this solution for $2 \mathrm{~min}$ and centrifuged for $5 \mathrm{~min}$ at $1500 \mathrm{rpm}$. The resulting mixture included two types of cells: Sertoli and spermatogonial cells. Cells in various groups were cultured in 10\% FBS in DMEM medium and incubated for $24 \mathrm{~h}$ prior to treatment with LIUS ( $37^{\circ} \mathrm{C}, 5.3 \% \mathrm{CO}_{2}$ ) (BINDER Co., German, Tuttlingen). Using immunocytochemistry, the Promyelocytic Leukemia Zinc Finger (PLZF) protein (Santa Cruz Biotechnology) (the marker for SSCs) was detected in spermatogonial cell-derived colonies. Secondary antibodies were FITC (fluorescein isothiocyanate) and RT (reverse transcriptase) (Santa Cruz Biotechnology), and DAPI (40.6-diamifino-2-phenylindole) (Santa Cruz Biotechnology) was used to stain cell nucleus [23].

The exposure time was selected under $\pm 1{ }^{\circ} \mathrm{C}$. The temperature of the plate containing the culture medium was controlled by a micro-thermometer during LIUS stimulation.

The effect of ultrasound waves was studied in a culture medium containing $10 \%$ FBS; 500,000 spermatogonial stem cells exposed to $40 \mathrm{kHz}$ ultrasound waves; mechanical indices of $0.40,0.51,0.75$ and 0.89 ; intensity of $0.28,0.45,0.96$, and $1.34 \mathrm{~W} / \mathrm{cm}^{2}$; the energy density of $20.16,18.90,32.64$, and $32.16 \mathrm{~J} / \mathrm{cm}^{2}$; exposure time of $72,42,34$, and $24 \mathrm{~s}$ for five consecutive days; and compared with control and sham groups. The cells were maintained in Dulbecco's Minimum Essential Medium (Gibco) supplemented with $10 \%$ fetal bovine serum (Gibco). Ultrasound stimulation was applied to SSCs cultured in an enclosed $3.5 \mathrm{~cm}$ tissue culture plate in another incubator $\left(37^{\circ} \mathrm{C}, 5.3 \% \mathrm{CO}_{2}\right)($ mini Galaxy E, Rs Biotech Co., UK, Irvine). It was sonicated through the bottom of the well through a coupling gel between the transducer and the plate. Each experiment was performed five times, for various sonication conditions.

After various stimulation intensities, SSCs were cultured for seven days. The colonies resulting from spermatogonial cells were assayed on the $7^{\text {th }}$ day with an invert-phase microscope (Zeiss, Germany) 
equipped with an ocular grid. Cell viability in different groups was compared with Trypan blue. Before measuring the number and diameter of the colonies, the microscope was calibrated.

The data of the viability rate and colonization of stimulated cells are presented as mean \pm standard deviation (SD). One-way ANOVA was run to analyze differences between groups at the significance level of 0.05 . All the data in this study were analyzed using SPSS statistical software.

\section{Results}

Minimum acoustic pressure changes were obtained at different points along the axis in the range of induced cavitation threshold 0.7 (potential hazard) [24], less or more than the threshold at different intensities with a radius of $1.8 \mathrm{~cm}$ (Fig. 1).

The axial contours of a $40 \mathrm{kHz}$ ultrasound transducer indicated that the near-field depth is $0.4 \mathrm{~cm}$. As the increasing intensity of ultrasound waves from 0.28 to $1.34 \mathrm{~W} / \mathrm{cm}^{2}$ on the target surface with a radius of $1.8 \mathrm{~cm}$, also showed an increase in acoustic pressure from $54.5 \mathrm{kPa}$ at $1.5 \mathrm{~cm}$ to $192 \mathrm{kPa}$ at $0.3 \mathrm{~cm}$ from the transducer surface.

The mechanical index changes in the near-field depth showed less volatility. The ultrasound mechanical index was related to the intensity of the waves. The increase in the mechanical index from 0.27 at $1.5 \mathrm{~cm}$ to 0.96 at $0.3 \mathrm{~cm}$ from the transducer area was estimated. In this study, the mean values of the mechanical index in minimum and maximum intensity were $0.27 \pm 0.05$ and $0.96 \pm 0.35$, respectively. Table 1 present the mean (SD) of mechanical indices in the $40 \mathrm{kHz}$ ultrasonic transducer. After selecting the intended intensity, the distance was selected as another effective parameter (Table 1).

Table 1 Mean and SD of mechanical indices in the $40 \mathrm{kHz}$ ultrasonic transducer

\begin{tabular}{|c|c|c|c|c|}
\hline $\begin{array}{l}\text { Intensity } \\
\left(\mathrm{W} / \mathrm{cm}^{2}\right)\end{array}$ & $\begin{array}{l}\text { Distance } \\
(\mathrm{cm})\end{array}$ & $\begin{array}{l}\text { Pressure } \\
(\mathrm{kPa})\end{array}$ & $\begin{array}{l}\text { Mechanical } \\
\text { Index }\end{array}$ & $\begin{array}{l}\text { Mechanical index } \\
\text { limit }\end{array}$ \\
\hline 0.28 & 0.50 & 81 & $0.14 \pm 0.40$ & $0.19<\mathrm{Ml}<0.58$ \\
\hline 0.45 & 0.50 & 103 & $0.17 \pm 0.51$ & $0.25<\mathrm{Ml}<0.73$ \\
\hline 0.96 & 0.50 & 151 & $0.26 \pm 0.75$ & $0.36<\mathrm{Ml}<1.07$ \\
\hline 1.34 & 0.50 & 178 & $0.30 \pm 0.89$ & $0.43<\mathrm{Ml}<1.27$ \\
\hline
\end{tabular}


In Table 1, the desired mechanical indices were estimated at the frequency of $40 \mathrm{kHz}$ with an intensity of $0.28,0.45,0.96$ and $1.34 \mathrm{~W} / \mathrm{cm}^{2}$ at a distance of $0.50 \mathrm{~cm}$ from the transducer surface. At the $0.5 \mathrm{~cm}$ distance, the radial profile of the mechanical index for $0.28 \mathrm{~W} / \mathrm{cm}^{2}$ intensity was $0.4 \pm 0.12$ (Fig. 2a). Figures $2 \mathrm{~b}$ and $2 \mathrm{c}$ respectively illustrate the acoustic pressure changes and the mechanical index changes for the intensity of $0.28 \mathrm{~W} / \mathrm{cm}^{2}$ at the distance of $0.5 \mathrm{~cm}$ from the transducer surface along the radial axis of the transducer.

In the center of the transducer, the mechanical index equaled 0.58. It gradually decreases when reaching 0.19 on the sides (Fig. 2a). The color change from blue to red showed an increase in acoustic pressure and mechanical index. In the validation results of a previous study [19], there was a significant correlation between the measured pressure and calculated pressure at $40 \mathrm{kHz}(\mathrm{p}<0.05)$.

Thermal control results are given in Fig. 3. The average time to increase $1^{\circ} \mathrm{C}$ in $0.40,0.51,0.75$, and 0.89 mechanical indices was about 72, 42, 34, and 24 s, respectively (Fig. 3).

The immunocytochemistry test for PLZF marker was clearly expressed in SSCs and colonies and thus the nature of these cells was confirmed. The colonies obtained after two steps of enzymatic digestion were spherical or elliptical with defined boundaries. To control the cultured cells, negative groups without added primary antibodies were brought to PLZF, and the expression of the genes was not observed due to the lack of antibodies, confirming the nature of cultured spermatogonial cells. DAPI was used to stain the nucleus. The qualitative study was performed by immunofluorescence to establish the nature of the resulting spermatogonial stem cells and for the qualitative evaluation of the specific protein markers of spermatogonial stem cells. The spermatogonial stem cell pluripotent activity is expressed in Fig. 4.

After the appearance of colonies in each group, the count and diameter of the colonies were extracted every day for seven days. According to the colony number data, the colony appearance time was equal in all groups (in the first 48 hours) (Fig. 5).

The number of colonies on the $7^{\text {th }}$ day was the highest $(93 \pm 4)$ in the group with the mean mechanical index of 0.40 and the lowest $(32 \pm 4)$ in the group with the mechanical index of 0.89 compared to the control group (65 \pm 4 ). There were significant differences among groups with 0.40 and 0.51 mechanical indices with all groups from the $5^{\text {th }}$ to the $7^{\text {th }}$ day $(p<0.05)$.

An increase in the diameter of the colony was observed in the group of 0.40 mechanical index in all the days of culture. The average diameter of colonies in the 0.40 mechanical index was $174.50 \pm 1.22 \mu \mathrm{m}$ (Fig. 6 ). From the $3^{\text {rd }}$ to the $7^{\text {th }}$ day before cell passages, there was a significant difference between the group with 0.40 mechanical index and the other groups $(p<0.05)$. There was no significant difference between the groups $(p=0.08)$. Cell viability was $100 \%$ in groups with $0.40,0.75$, and 0.89 mechanical indices and controls, and it was $98 \%$ and in the group with 0.51 mechanical index and the sham group. The percentage error was very low, approximately $0.0 \%$ to $1.4 \%$, in various groups. 


\section{Discussion}

LIUS is non-physiological mechanical energy which inserts direct mechanical stress into cultured cells and is a type of noninvasive mechanical stimulation. In physiological conditions of $37^{\circ} \mathrm{C}$ and using low intensity, non-thermal effects can be dominant, and the main interaction, i.e. acoustic cavitation, is important. According to the studies, stable cavitation without collapse and the ability to apply stress without chemical activities produce beneficial effects in low intensities. The mechanical index parameter is the quantity that will define the phenomenon of acoustic cavitation $[14,15,24]$. Cavitation threshold for generating the bioeffects of low-frequency ultrasound have been reported, but these vary with the type of cell or tissue being studied. Hill [24] reported that, in 0.25 to $3 \mathrm{MHz}$ frequencies, the intensity threshold for inertial cavitation in a liquid suspension of cells was $1 \mathrm{~W} / \mathrm{cm}^{2}$. At $20 \mathrm{kHz}$, the threshold to produce observable lesions in human skin was determined to be $2.5 \mathrm{~W} / \mathrm{cm}^{2}(\mathrm{Ml}=1.94)$ in vitro, which can be considered a hazard limit for contact to human skin [26].

On the other hand, the biological activity of low-frequency ultrasound waves is the result of the stimulation of cells by combining stable cavities and effective acoustic streams in vitro [28]. Ebrahiminia [27] investigated the exposure parameters in LIUS in near fields of $40 \mathrm{kHz}$ and $1 \mathrm{MHz}$ by an iodide chemical dosimeter. Results indicated that the dosimeter absorption is higher in the continuous mode of sonication than the pulse mode. Results have been shown to be most frequent in $40 \mathrm{kHz}$. These experimental results are similar to the modeling results of the mechanical index. Hideo (2009) [11] examined the frequencies of 41,158 , and $445 \mathrm{kHz}$, reporting a reduction in cavitation by increasing the frequency and its maximum at the intensity of $300 \mathrm{~mW} / \mathrm{cm}^{2}$ and $41 \mathrm{kHz}$. The results of these studies are consistent with the results of calculating the mechanical index that represents cavitation.

Furthermore, LIUS is an acoustic pressure wave that can produce localized mechanical stimulation for cells to conduct the activity of cellular membrane tensile receptors, ion channels, and integrin (extracellular messages). There is growing evidence that integrins are promising candidates for sensing extracellular matrix-derived mechanical stimuli and converting them into biochemical signals. Thus, there is growing evidence that integrins are promising candidates for sensing extracellular matrix-derived mechanical stimuli and converting them into biochemistry signals [17]. Consequently, low-intensity ultrasound waves can stimulate transmembrane proteins such as integrin to divide and can enter these cells into a mitotic process in order for self-renewal or differentiation pathway.

A significant increase in proliferation of SSCs in the mechanical index of 0.40 was shown. An increase in proliferation was observed in the 0.51 mechanical index group, so that in comparison with 500,000 cells, it was respectively $2.89 \pm 0.07$ and $2.17 \pm 0.10$ in the two groups. The effects of secondary factors, i.e. LIUS, growth, and proliferation of SSCs, have been well observed in cell groups. Mohaqiq et al. [7] showed the continuous LIUS of $200 \mathrm{~mW} / \mathrm{cm}^{2}$ causes a significant increase of $2.26 \pm 0.03$ times in the proliferation of initial cells compared to controls ( $1.63 \pm 0.03$ times) after seven days of cultivation. 
The effect of low-intensity ultrasound stimulation on the proliferation and reproductivity of HepG2 and 3Т 3 cells in vitro was examined with a $1.06 \mathrm{MHz}$ generator by changing the parameters [29]. Cell viability and reproductivity at different time after sonication were measured by MTT and colony formation assay. The results illustrated that ultrasound irradiation at $0.4-0.8 \mathrm{~W} / \mathrm{cm}^{2}$ and a high pulse repetition frequency $(100 \mathrm{~Hz})$ can facilitate cell proliferation, while above $0.8 \mathrm{~W} / \mathrm{cm}^{2}$ would resist it. Therefore, cellular responses to low-intensity ultrasound are parameter-dependent. Jong (2009) [30] studied mesenchymal stem cells derived from the human umbilical cord and showed that $40 \mathrm{kHz}$ LIUS, intensity less than 25 to $35 \mathrm{~mW} / \mathrm{cm}^{2}$, periods of 100,300 , or $600 \mathrm{~s}$, and a duty factor of $50 \%$ improve the proliferation of mesenchymal stem cells derived from the human umbilical cord.

Considering the effect of the LIUS mechanical index parameter, in this study, an increase was observed in the colony's diameter in the group with the mechanical index of 0.40 with the average diameter of the colony being $174.50 \pm 1.22 \mu \mathrm{m}$. Moreover, a reduction in colony diameter was found in the group with a 0.89 mechanical index with the mean diameter of the colony being $137.45 \pm 1.03 \mu \mathrm{m}$ in comparison with the control group $(154.7 \pm 1.78 \mu \mathrm{m})$ and the sham group $(139.52 \pm 0.62 \mu \mathrm{m})$. The number of colonies on the $7^{\text {th }}$ day of culture compared to the control group were the highest in the group with 0.40 mechanical index $(93 \pm 4)$ and the least $(32 \pm 4)$ in the group with 0.89 mechanical index. The number of colonies on the $7^{\text {th }}$ day of culture in control group, sham group, and groups with 0.51 and 0.75 mechanical indices equaled $65 \pm 4,38 \pm 1,73 \pm 2$, and $35 \pm 2$, respectively.

This study is similar to the study by Xu [18] reporting the effect of LIUS on hematopoietic stem cells in five days of radiation and an increase in cell proliferation, colonization, and viability.

Lim et al. [31] studied the effects of low-intensity ultrasound on the proliferation and osteogenic differentiation of human alveolar bone-derived mesenchymal stem cells (hABMSCs). Gene expression indicated that LIPUS treatment had a positive influence on the expression of mRNA for ALP and Col-I. These results suggest that LIUS treatment may affect the cell viability and osteogenic differentiation of hABMSCs.

Finally, according to other studies, the bio-stimulating effects of LIUS irradiation promote proliferation and maintain cell viability, and better results can be achieved by selecting the optimum parameters. Thus, the results of the present study indicate the effect of 0.40 mechanical index on proliferation and colonization of SSCs for the first time.

The mechanical index has been introduced to control the risks of diagnostic and clinical applications of ultrasound. Therefore, it is necessary to determine the limit of mechanical index affecting cultured cells. In the study by Kotopulis et al. [32], to avoid dangers and harm to babies' lung, a mechanical index less than 0.3 and, to prevent damage to the intestine, a mechanical index between 0.3 and 0.7 were proposed. Moreover, in the study by Hlinomazova [33], the mechanical index of 0.23 for eye applications was introduced in an FDA report. According to studies on the mechanical index range of cavitation threshold, the mechanical indices in culture media are less than 0.7 because the eye tissue and culture medium are 
made of water-equivalent material. Thus, considering the cavitation threshold of different materials, it is essential to find effective mechanical indices for proliferation and colonization.

\section{Conclusions}

According to the results, SSCs in the level of the mechanical index parameter show increases in cell proliferation and colonization. LIUS in the fine mechanical index can be an effective strategy for improving culture and the results of stem cell enrichment.

\section{References}

1. Wu H, Ren K, Zhao W, Baojian GE, Peng S. Effect of electromagnetic fields on proliferation and differentiation of cultured mouse bone marrow mesenchymal stem cells. J Huazhong Univ Sci Technolog Med Sci. 2005;25(2):185-7.

2. Church CC, Labuda C, Ightingale K. A theoretical study of inertial cavitation from acoustic radiation force impulse imaging and implications for the mechanical index. Ultrasound Med Biol. 2015;41(2): 472-85.

3. Eduardo FdeP, Bueno DF, de Freitas PM, Marques MM, Passos-Bueno MR, Eduardo CdeP, Zatz M. Stem cell proliferation under low-intensity laser irradiation: A preliminary study. Lasers Surg Med. 2008;40(6):433-8.

4. Tassinary JAF, Lunardelli A, Basso BS, Dias HB, Catarina AV, Stülp S, Haute GV, Martha BA, Melo DADS, Nunes FB, Donadio MVF, Oliveira JR. Low-intensity pulsed ultrasound (LIPUS) stimulates mineralization of MC3T3-E1 cells through calcium and phosphate uptake. Ultrasonics 2018;84:2905 .

5. Ruan JL, Wang YN, Crum LA, Mitchell SB. Ultrasound generated mechanical induction of mesenchymal stem cells. J Acoust Soc Am. 2010;127(1941):1763-6.

6. Lai CH, Chuang CC, Li JK, Chen SC, Chang WH. Effects of ultrasound on osteotomy healing in a rabbit fracture model. Ultrasound Med Biol. 2011;37(10):1635-43.

7. Mohaqiq M, Movahedin M, Mokhtari-Dizaji M, Mazaheri Z. Investigation on the effect of low intensity ultrasound stimulation on mouse spermatogonial stem cell proliferation and colonization. ASJ. 2013;10(3):119-24.

8. Turksen K. Adult stem cell. Human Press Inc, New Jersey 2004;Chap 2:19-35.

9. Mclaren A. Genetics and human reproduction. Trends Genet 1998;14(10):427-31.

10. Oatley JM, Reeves JJ, Mclean DJ. Biological activity of cryopreserved bovine spermatogonial stem cells during in vitro culture. Biol 2004;71(3):942-7. 
11. Hideo U, Mizue M, Toshinobu S, Daisuke K, Yasunori M. Acoustic cavitation as an enhancing mechanism of low-frequency sonophoresis for transdermal drug delivery. Biol Pharm Bull. 2009;32(5):916-20.

12. Legay M, Gondrexon N, Person SL, Boldo P. Enhancement of heat transfer by ultrasound: Review and recent advances. Int J Chem Eng, 2011;17:1-17.

13. Barati AH, Mokhtari-Dizaji M. Ultrasound dose fractionation in sonodynamic Ultrasound Med Biol. 2010;36(6): 880-7.

14. Hasanzadeh H, Mokhtari-Dizaji M, Bathaie SZ, Hassan ZM, Nilchiani VH. Enhancement and control of acoustic cavitation yield by low-level dual frequency sonication: A subharmonic analysis. Ultrason Sonochem. 2011;18(1):394-400.

15. Winklund M. Acoustofluidic 12: Biocompatibility and cell viability in microfluidic acoustic resonators. Lab Chip 2012; 12: 2018- 2028.

16. Baker KG, Robertson VJ, Duck FA. A review of therapeutic ultrasound: Biophysical effects. Phys Ther. 2001;81:1351-8.

17. Zhou SH, Schmelz A, Seufferlein Th, Li Y, Zhao J. Molecular mechanisms of low intensity pulsed ultrasound in human skin fibroblasts. J Biol Chem. 2004;279(52):54463-9.

18. Xu P, Gul-Uludag H, Ang W, Yang X, Huang M, Marquez-Curtis L, Mcgann L, Janowska-Wieczorek A, Xing J, Swanson E, Chen J. Low-intensity pulsed ultrasound-mediated stimulation of hematopoietic stem/progenitor cell viability, proliferation and differentiation in vitro. Biotechnol Lett 2012;34(10):1965-73.

19. Hormozi-Moghaddam Z, Mokhtari-Dizaji M, Movahedin M, Ravari ME. Estimation of the distribution of low-intensity ultrasound mechanical index as a parameter affecting the proliferation of spermatogonial stem cells in vitro. Ultrason Sonochem. 2017;37:571-81.

20. Sarvazyan AP, Urban MW, Greenleaf JF. Acoustic wave in medical imaging and diagnostics. Ultrasound Med Biol. 2013;39(7):1133-46.

21. Ahmadi F, McLoughlin IV. A new mechanical index for gauging the human bioeffects of low frequency ultrasound. Int Conf IEEE EMBS. 2013: 1964-7.

22. AVMA Guidelines for the Euthanasia of Animals: 2013 Edition AVMA.org., 2013.

23. Ketkar AA, Reddy KVR. Expression pattern of OCT-4 and PLZF transcription factors during the early events of spermatogenesis in mice. J Cell Sci Ther. 2012;3:1-6.

24. British Medical Ultrasound Society (BMUS). Guidelines for the safe use of diagnostic ultrasound equipment. Ultrasound 2010; 18:52-58.

25. Hill CR. Ultrasonic exposure thresholds for changes in cells and tissues. J Acoust Soc Am 1972; 52: 667-72.

26. Boucaud A, Montharu J, Machet L, Arbeille B, Machet MC, Patat F, Vaillant L. Clinical, histologic, and electron microscopy study of skin exposed to low-frequency ultrasound. Anatomic Rec. 2001;264(1):114-9. 
27. Li E. Chromatin modification and epigenetic reprogramming in mammalian development. Nat Rev Genet. 2002;3(9):662-73.

28. Ebrahiminia A, Mokhtari-Dizaji M, Toliyat T. Correlation between iodide dosimetry and terephthalic acid dosimetry to evaluate the reactive radical production due to the acoustic cavitation activity. Ultrason Sonochem. 2013;20(1):366-72.

29. Chunmei Y, Xuehui J, Kang D, Qiliang C. Effects of low intensity ultrasound on cell proliferation and reproductivity. Trans Tianjin Uni. 2016;22(2):125-31.

30. Jong HY, Eun YR, Sue SH, Nam HJ, Eun YS, Dong SL, Kyou SH, Joung SK, Byoung JK, Hye WJ, Kang SY. Introducing pulsed low-Intensity ultrasound to culturing human umbilical cord-derived mesenchymal stem cells. Biotechnol Lett J. 2009;31(3):329-35.

31. Lim K, Kim J, Seonwoo H, Park SH, Choung PH, Chung JH. In vitro effects of low intensity pulsed ultrasound stimulation on the osteogenic differentiation of human alveolar bone-derived mesenchymal stem cells for tooth tissue engineering. Biomed Res Int. 2013;3:269724.

32. Kotopulis S. Biomedical ultrasonic, cavitation and sonoporation. Thesis for the degree of doctor philosophy; Hull University; 2011,Chap 1:11-84

33. Hlinomazova Z, Hrazdira I. Alara-principle and safety problems of diagnostic SCRIPTA Medica (BRNO) 2005;78(6):341-6.

\section{Declarations}

\section{- Ethics approval and consent to participate}

The present study was conducted under the protocol approved by the Animal Experimental Committee of the Medical Sciences Faculty of Tarbiat Modares University.

\section{- Consent for publication}

Not applicable.

\section{- Availability of data and materials}

The analyzed data sets generates during the study are available from the corresponding author on reasonable request. 
The authors declare that they have no competing interests.

\section{-Funding}

None.

\section{-Authors' Contributions}

All authors ZHM, MMD and MM have made substantial contributions to all of the conception and design of the study, acquisition of data, analysis and interpretation of data, drafting the article or revising it critically for important intellectual content, submitting of final approval of the version. ZHM, MMD and $\mathrm{MM}$ were responsible of the research design. ZHM and MMD wrote the final version of the manuscript. All authors had read and approved the final manuscript.

\section{-Acknowledgments}

This study was approved by the Faculty of Medical Sciences, Tarbiat Modares University. This work was partially supported by the Iranian National Science Foundation (INSF).

\section{Figures}




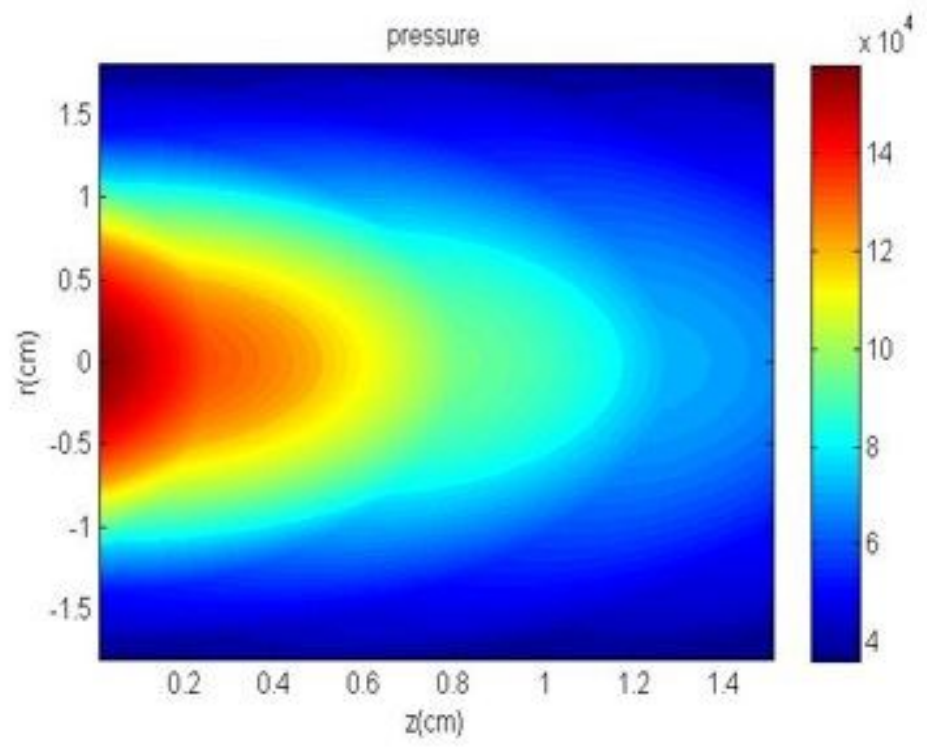

\section{Figure 1}

The axial contour map of the $40 \mathrm{kHz}$ ultrasonic transducer acoustic pressure $(\mathrm{Pa})$ in the r-z screen and the intensity of $0.28 \mathrm{~W} / \mathrm{cm} 2$; the horizontal axis shows the $z$-axis $(\mathrm{cm})$ and the vertical axis shows the minimal acoustic pressure $(\mathrm{Pa})$. Color changes from blue to red demonstrate increasing minimal acoustic pressure.

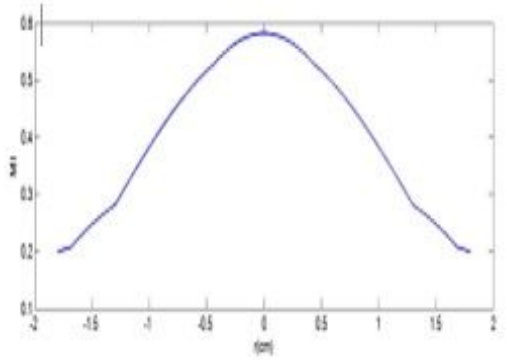

(a)

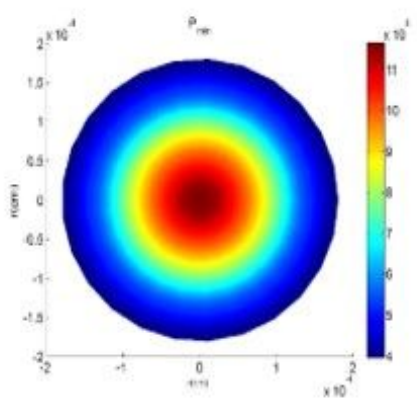

(b)

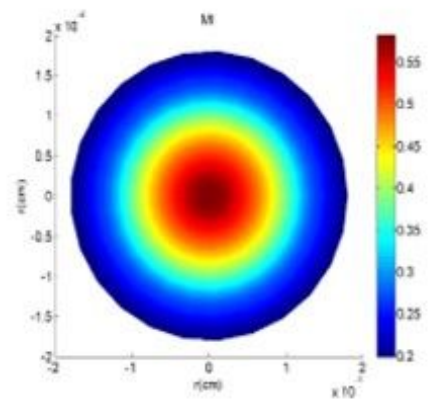

(c)

Figure 2 
a) Mechanical index curve along the radial axis of the transducer, b) acoustic pressure map; c) mechanical index map; for $40 \mathrm{kHz}$ frequency, $0.28 \mathrm{~W} / \mathrm{cm} 2$ intensity, $0.5 \mathrm{~cm}$ distance from the surface of the transducer with 0.40 average mechanical index.
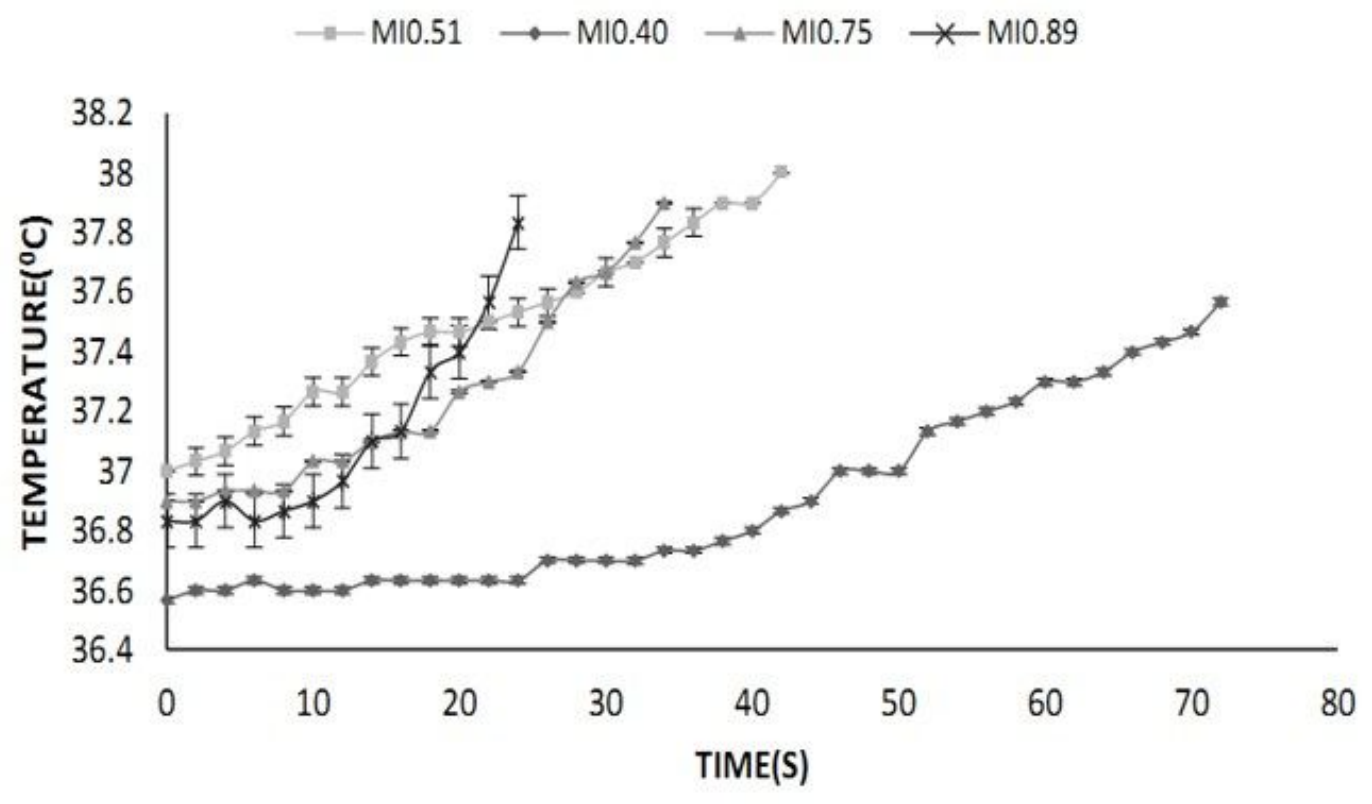

Figure 3

The enhancement curve of culture medium temperature (mean \pm SD) after sonication with different mechanical indices $(0.40,0.51,0.75$, and 0.89$)$

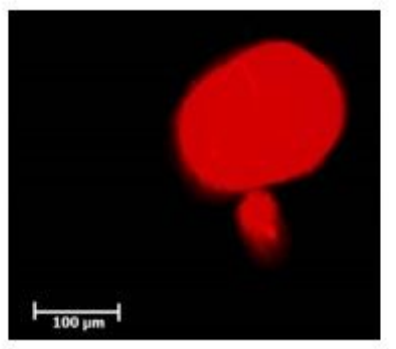

(a)

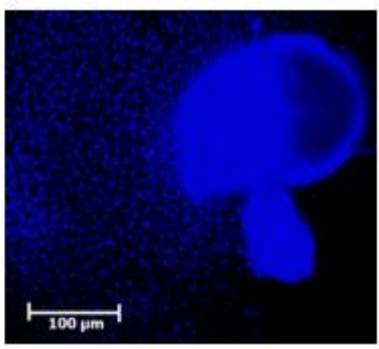

(b)

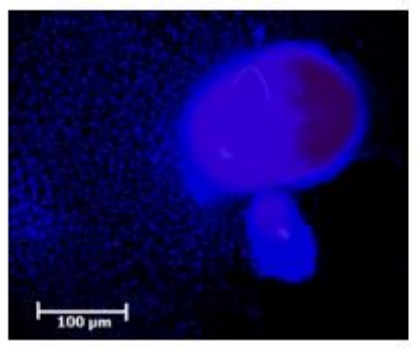

(c)

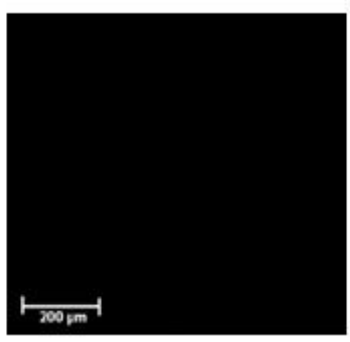

(d) 
Figure 4

Immunofluorescent staining of SSCs, detection PLZF positive cells, a) PLF positive observed on the obtained colonies, b) staining nuclear cells with DAPI, c) merge cells from a and b, d) the negative control image (Pictures do not contain initial antibody (PLZF).) (TE 2000 Nikon Eclipse fluorescent microscope)

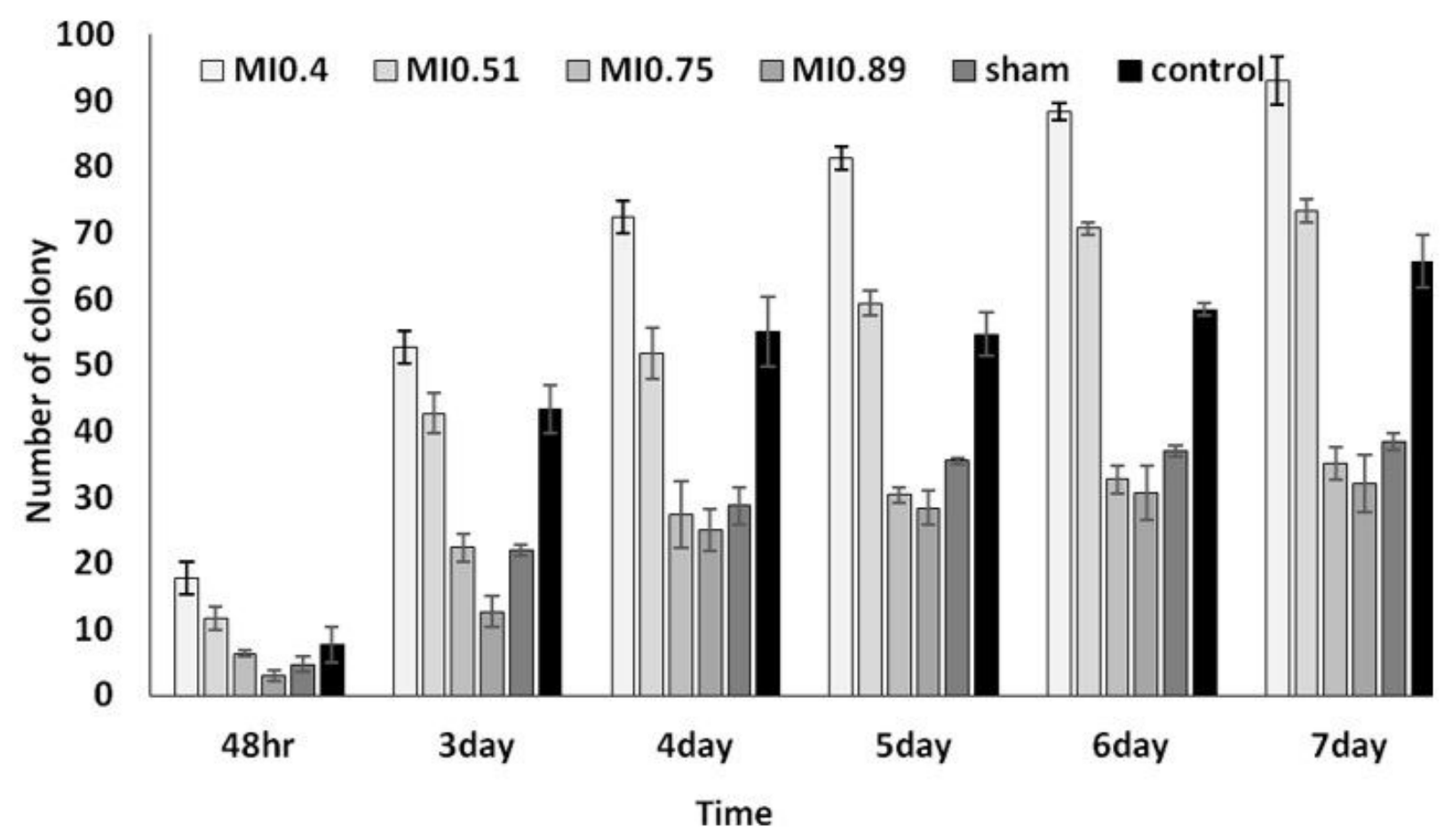

Figure 5

The number of colonies (mean \pm SD) from the first 48 hours to seven days in experimental groups with $0.40,0.51,0.75$, and 0.89 mechanical indices, control, and sham groups 


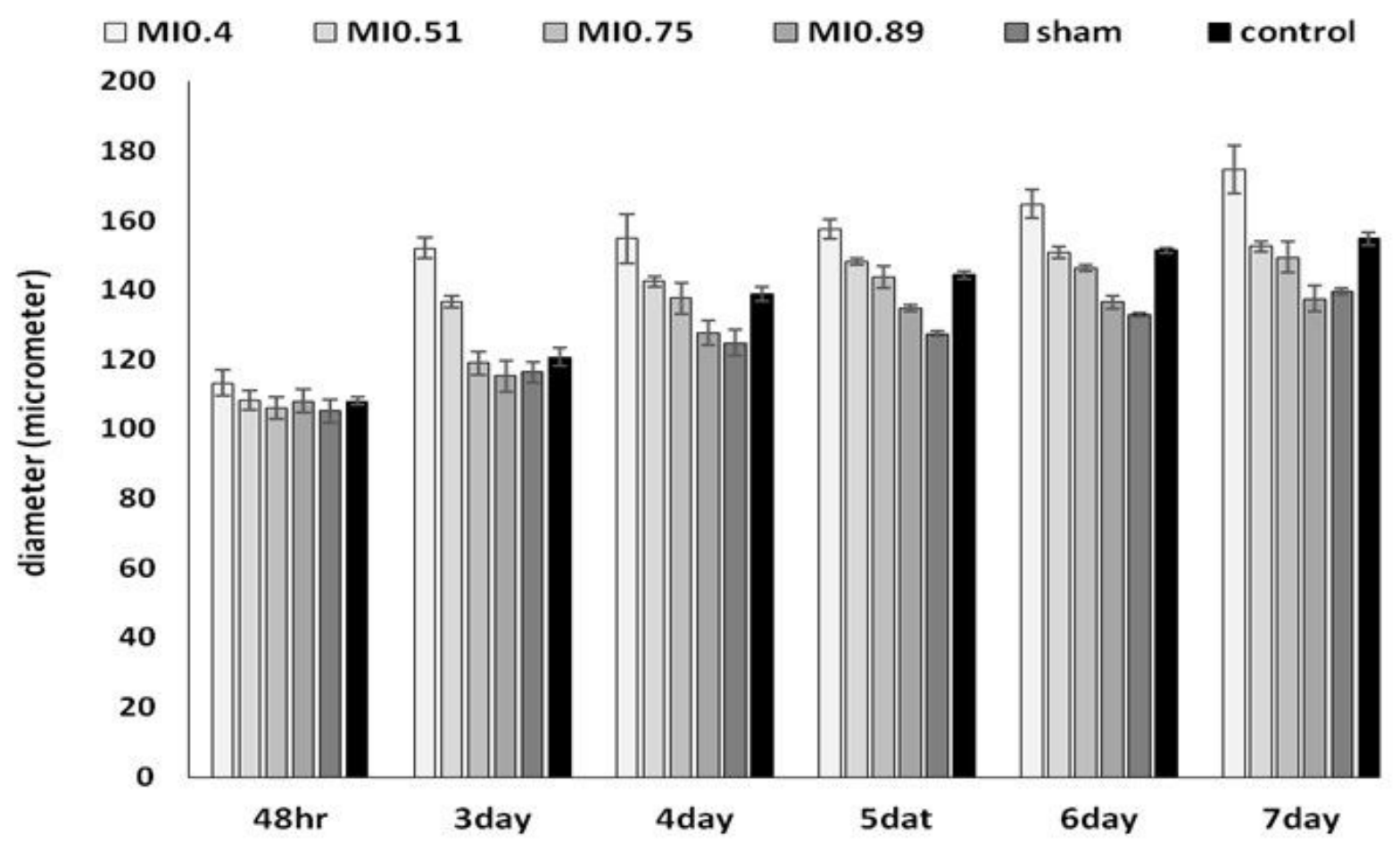

Figure 6

The diameter of colonies (mean $\pm S D$ ) from the first 48 hours to the 7th day in experimental groups with $0.40,0.51,0.75$, and 0.89 mechanical indices, control, and sham groups

\section{Supplementary Files}

This is a list of supplementary files associated with this preprint. Click to download.

- checklistfillableconverted.pdf 